\title{
FICUS CARICA AND ITS CONSTITUENTS ROLE IN MANAGEMENT OF DISEASES
}

\author{
ARSHAD H RAHMANI*1, YOUSEF H ALDEBASI ${ }^{2}$ \\ ${ }^{1}$ Department of Medical Laboratories, College of Applied Medical Sciences, Qassim University, Saudi Arabia. ${ }^{2}$ Department of Optometry, \\ College of Applied Medical Sciences, Qassim University, Saudi Arabia. Email: rehmani.arshsad@gmail.com
}

Received: 30 January 2017, Revised and Accepted: 14 April 2017

\section{ABSTRACT}

Alternative medicines or formulation based on natural sources are good option in diseases cure and prevention. Ficus carica is member of Moraceae family and its health management properties have been mentioned in religious books and traditional medicines. It holds various constituents including phenolic compounds, minerals and vitamins and such ingredient shows role in disease cure. Studies based on in vivo and in vitro reported that figs fruits, stem, leaves, and latex have health management effect through antioxidant, anti-inflammatory effects, antimicrobial, anticarcinogenic, and anti-inflammatory effects. Moreover, an inverse correlation between figs use and development of disease has been noticed. Despite its implications in disease management, little is known about their mechanism of action. In this review, efforts are made based on in vivo and in vitro studies to illuminate the role of $F$. carica leaves and fruits in the prevention of diseases.

Keywords: Ficus carica, Antioxidant, Anti-inflammatory effect, Health management.

(c) 2017 The Authors. Published by Innovare Academic Sciences Pvt Ltd. This is an open access article under the CC BY license (http://creativecommons. org/licenses/by/4. 0/) DOI: http://dx.doi.org/10.22159/ajpcr.2017.v10i6.17832

\section{INTRODUCTION}

Medicinal plants and their constituents have been extensively used as health promoting effect. Epidemiological studies have proven that natural product has disease cure potentiality through modulation of physiological and biological activities. Medicinal plants and its constituents have confirmed their role in diseases prevention and treatment $[1,2]$. In this vista, Ficus carica and its ingredients have confirmed diseases preventive ability.

F. carica is generally known as fig, and it is a small deciduous tree native to Asia Minor, Persia, Syria and the Mediterranean region [3]. Ficus is a member of Moraceae family which cover one of the chief genera of angiosperms with approximately 800 species of trees, shrubs, hemiepiphytes, climbers, and creepers in the tropics and subtropics [4]. A country such as Turkey, Egypt, Morocco, Spain, Greece, California, Italy, and Brazil are chief producers and also in hot, dry summers and mild winters countries [5]. Its health beneficial effect has been mentioned in religious books including Bible and Quran. In sura al-Teen of Quraan, the medicinal benefit is discussed as "I swear by the fig and the Olive" (Sura no. 95 verse no. 1). Moreover, its health promoting effect has mentioned as Hazrat Abu Darda (Radiallaho Anho) narrates Prophet Mohammad (Peace Be Upon Him) said, "Eat fig, it cure the piles and is useful in rheumatism" [6]. Leaves of figs traditionally used in the management of diseases such as vitiligo, diabetes, coughs, asthma, constipation, and gingivitis [3,7]. Moreover, roots used in the treatment of leukoderma and ringworms and fruits also shows role as antipyretic, purgative, aphrodisiac properties, and have shown to be valuable in inflammations and paralysis [8,9]. A study has summarized the various activities of $F$. carica [10], and another previous studies reported that latex and its derivatives have been revealed to suppress the growth of transplanted and spontaneous tumors [11,12]. In this review, we focused the health beneficial effects of as antioxidant, antiinflammatory effects, and antimicrobial, anticarcinogenic, and antiinflammatory effects.

\section{BOTANICAL DESCRIPTION OF F. CARICA}

Fig ( $F$. carica $\mathrm{L}$.) is one of the traditional Mediterranean species belongs to family of Moraceae. Tree of $F$. carica L is generally tall as $15-20 \mathrm{ft}$ that has numerous spreading branches and a trunk more than $7 \mathrm{ft}$ in diameter [13]. Its leaves are long with multi-lobes. Ficus cover one of the major genera of angiosperms with approximately 800 species of trees, shrubs, hemiepiphytes, climbers, and creepers in the tropics and subtropics worldwide [4]. Detailed botanical information is discussed below [14].

Kingdom: Plantae

Division: Magnoliophyta

Class: Magnoliopsida

Order: Rosales

Family: Moraceae

Genus: Ficus

Species: F. carica.

\section{INGREDIENTS OF F CARICA}

F. carica contains various valuable constituents in fruits and leaves (Table 1). The majority species of F. carica hold constituents such as phenolic compounds, organic acids, and volatile compounds $[15,16]$. Fruits constitute various valuable ingredients including cyanidin-3O-glucoside, cyanidin-3-Orhamnoglucoside, saturated fat, cholesterol, and sodium, insoluble sugars, protein, vitamin A, vitamin C, calcium, iron [17]. The study based on phytochemical analysis confirmed that the aqueous extract of ripe dried fruit contain alkaloids, flavonoids, coumarins, saponins, and terpenes $[18,19]$. The leaves have been reported to have furanocoumarins including psoralen, bergapten, xanthotoxin [20] and triterpenes such as calotropenyl acetate and lupeol acetate [21]. The other valuable ingredients are phenolics, anthocyanins, fructose, glucose, and sucrose were identified from the figs [22] and the previous finding reported that fruit has phytosterols [23].

\section{ROLE OF F. CARICA IN DISEASES PREVENTION}

F. carica hold various constituents and ingredients shows pivotal role in the disease management (Table 2) and its role is explained as.

\section{Antioxidant activity}

Medicinal plants and their ingredients show therapeutics role in diseases cure and prevention due to the rich source of antioxidant [24]. In this regards, F. carica shows health promoting effect due to the 
Table 1: Chief ingredients of $\boldsymbol{F}$ carica

\begin{tabular}{lll}
\hline Parts of F carica & Constituents & References \\
\hline Fruits & Cyanidin-3-O-glucoside, cyanidin-3-Orhamnoglucoside, saturated fat, cholesterol, sodium, insoluble sugars, & {$[18]$} \\
& protein, vitamin A, vitamin C, calcium, iron & \\
Ripe dried fruit & Alkaloids, flavonoids, coumarins, saponins, and terpenes & {$[19,20]$} \\
Dried seeds & Fixed oil including fatty acids & {$[15]$} \\
Leaves & Furanocoumarins including psoralen, bergapten, xanthotoxin, triterpenes such as calotropenyl acetate and & {$[21,22]$} \\
& lupeol acetate & \\
Leaves & 3-O- and 5-O-caffeoylquinic acids, ferulic acid, quercetin-3-O-glucoside, quercetin-3-O-rutinoside and psoralen & {$[15]$} \\
\hline
\end{tabular}

F. carica: Ficus carica

Table 2: Pharmacological activity of different parts of $F$. carica

\begin{tabular}{|c|c|c|c|}
\hline $\begin{array}{l}\text { Plants } \\
\text { parts }\end{array}$ & Pharmacological activities & Finding/outcome of the study & References \\
\hline Fruits & Antioxidative & Extract showed effective scavenging activities & [26] \\
\hline Branches & $\begin{array}{l}\text { Antioxidant and } \\
\text { anti-inflammatory }\end{array}$ & $\begin{array}{l}\text { Study finding demonstrated that branches of figs possessed pharmacological } \\
\text { activity and might be useful for developing antioxidant or anti-inflammatory agents }\end{array}$ & {$[27]$} \\
\hline Leaves & Anti-inflammatory & $\begin{array}{l}\text { Study result confirmed that extract showed anti-inflammatory effect, that was } \\
75.90 \% \text { in acute inflammation and in chronic study it was } 71.66 \% \text { reduction in } \\
\text { granuloma weight }\end{array}$ & {$[28]$} \\
\hline Leaves & Anti-pyretic & Extract showed significant dose-dependent reduction in normal body temperature & [31] \\
\hline Latex & Anticancer & Inhibition of growth of stomach cancer cell line was noticed & [30] \\
\hline Latex & Anticancer & $\begin{array}{l}\text { Latex and its derivatives have been revealed to suppress the growth of transplanted } \\
\text { and spontaneous tumors }\end{array}$ & {$[11,12]$} \\
\hline Fig latex & Anticancer & $\begin{array}{l}\text { 6-0-acyl-beta-D-glucosyl-beta-sitosterols showed inhibitory effects on proliferation } \\
\text { of cancer cell lines }\end{array}$ & {$[32]$} \\
\hline Stem bark & Anti-diabetic & $\begin{array}{l}\text { Extract showed significant protection and lowered the blood glucose levels to } \\
\text { normal }\end{array}$ & {$[35]$} \\
\hline Leaves & Anti-diabetic & $\begin{array}{l}\text { Aqueous extract showed hypoglycemic activity in treated versus non-treated } \\
\text { diabetic rats }\end{array}$ & {$[36]$} \\
\hline Leaves & Hepato-protective & Leaves extract demonstrated important hepatoprotection dose-dependent manner & {$[38]$} \\
\hline Latex & Antibacterial & $\begin{array}{l}\text { Ethyl acetate extract showed inhibition effect on the multiplication of bacteria } \\
\text { species and for the opportunist pathogenic yeasts }\end{array}$ & [43] \\
\hline $\begin{array}{l}\text { Latex } \\
\text { extract }\end{array}$ & Anti-angiogenic & $\begin{array}{l}\text { Results of the study confirmed that latex extract could inhibit proliferation and } \\
\text { capillary tube }\end{array}$ & {$[46]$} \\
\hline Leaves & Anti-angiogenic & $\begin{array}{l}\text { Finding observed that the extract dose dependently inhibited the tube formation of } \\
\text { HUVECs }\end{array}$ & {$[47]$} \\
\hline Latex & Antiviral & $\begin{array}{l}\text { Simultaneous addition of F-latex and CpHV-1 to monolayers of MDBK cells resulted } \\
\text { in a significant reduction of CpHV-1 titers }\end{array}$ & {$[45]$} \\
\hline Fruits & Antispasmodic & $\begin{array}{l}\text { Study results showed the presence of spasmolytic activity in the ripe dried fruit } \\
\text { mediated through the activation of K+ATP channels }\end{array}$ & [49] \\
\hline Leaves & Immunomodulatory & $\begin{array}{l}\text { Administration of extract remarkably ameliorated both cellular and humoral } \\
\text { antibody response }\end{array}$ & {$[50]$} \\
\hline Latex & Anthelmintic & $\begin{array}{l}\text { Results of the study confirmed that latex administered in was effective in the } \\
\text { removal of S. obvelata }\end{array}$ & {$[51]$} \\
\hline Leaves & Anti-nematicidal & Finding result confirmed leaf extract showed the strongest nematicidal activity & [52] \\
\hline Leaves & Sperm parameters & $\begin{array}{l}\text { Leaf extracts improved sperm count, non-progressive motility of spermatozoa, and } \\
\text { gonadosomatic index }\end{array}$ & [55] \\
\hline Fruits & Nephroactivity protective & $\begin{array}{l}\text { HEFC supplementation ameliorated GM-induced specific metabolic alterations and } \\
\text { oxidative damage due to its intrinsic biochemical/antioxidant properties }\end{array}$ & {$[60]$} \\
\hline Leaves & Inhibitor of osteoclastogenesis & $\begin{array}{l}\text { Study results showed that hexane soluble fraction is a potent inhibitor of } \\
\text { osteoclastogenesis }\end{array}$ & {$[61]$} \\
\hline Leaves & $\begin{array}{l}\text { Effect on ischemia/reperfusion } \\
\text { injuries }\end{array}$ & $\begin{array}{l}\text { Leaf extract decreased number of VEBs, incidence and duration of rev VF with clear } \\
\text { reduction in infarct size and infarct volume }\end{array}$ & {$[62]$} \\
\hline
\end{tabular}

VF: Ventricular fibrillation, VEBs: Ventricular ectopic beats, HUVEs: Human umbilical vein endothelial cells, F. carica: Ficus carica

rich source of antioxidant. A study was performed to determine the antioxidant activity, and results of the study revealed that antioxidant activity was found to be very good [25]. Antioxidative activities of water extract and crude hot-water soluble polysaccharide (PS) from fruit was investigated and finding confirmed that both water extract and crude hot-water soluble PS showed prominent scavenging activities with the effective concentration values of 0.72 and $0.61 \mathrm{mg} / \mathrm{ml}$, respectively [26]. Furthermore, The PS also showed a significant increase in the clearance rate of carbon particles and serum hemolysin level of normal mice [26].
Another study was carried out based on preparation of ethanol extract and its ethyl acetate, hexane, butanol, and water fractions and examined for scavenge free radicals potentiality. Results data revealed that the ethyl acetate fraction hold the largest amount of phenolic compounds and showed the highest free radical scavenging activity [27].

\section{Anti-inflammatory effect}

Inflammation is a natural response of body against microorganism and toxic materials. Various medicinal plants have proven their role as anti- 
inflammatory agent without any severe side effect. Experiment was performed based on different types extract of fig branches to examine abilities to scavenge free radicals and inhibit inflammatory reactions. Finding of the study revealed that the ethyl acetate fraction contained the largest amount of phenolic compounds and showed the highest free radical scavenging activity. Furthermore, all fraction of fig, especially ethanol extract and the ethyl acetate and hexane fractions inhibited nitric oxide production in RAW264.7 cells [27]. Another experiment was performed to check the effect of anti-inflammatory activity of leaves through different types of extract. Finding of the study demonstrated that ethanolic extract showed maximum anti-inflammatory effect that was $75.90 \%$ in acute inflammation and in chronic study showed $71.66 \%$ reduction in granuloma weight [28]. Furthermore, extract such as petroleum ether, chloroform, and ethanol showed significantly reduced edema [28].

\section{Antipyretic effect}

Commonly used antipyretic drugs are toxic to liver cells and cause complications. Antipyretic effect of ethanol extract of leaves was evaluated and extract at doses of 100,200 , and $300 \mathrm{mg} / \mathrm{kg}$ body wt. showed significant dose-dependent reduction in normal body temperature and yeast-provoked elevated temperature [29].

\section{Anti-cancer activity}

F. carica shows role as antitumor through inhibitory effects on proliferation of various cancer cell lines. A study was carried out to check the anticancer effect of latex in different concentration and finding showed that $5 \mathrm{mg} / \mathrm{ml}$ concentration had the greatest effect in inhibition of stomach cancer cell line growth [30]. Another study reported that latex and its derivatives have been showed to suppress the growth of transplanted and spontaneous tumors [11,12]. Cytotoxicity of fruit and leaf extracts as well as the latex on HeLa cell line was examined and results showed that latex and different extracts could reduce the viability of HeLa cells at concentrations as low as $2 \mu \mathrm{g} / \mathrm{mL}$ in a dosedependent manner [31]. A mixture of 6-0-acyl-beta-D-glucosyl-betasitosterols was isolated as an effective cytotoxic agent from fig latex and result confirmed in vitro inhibitory effects on proliferation of various cancer cell lines [32]. Antiproliferative activity of F. carica (fig) latex (FCL) and the effect of the FCL-temozolomide (TMZ) combination were examined in the cell lines such as T98G, U-138 MG, and U-87 MG glioblastoma multiforme (GBM) and data of the results showed latex FCL causes cell death in GBM cells with different responses to TMZ, and this effect is synergistically increased in combination with TMZ [33]. Anticancer effect of fig tree latex on human cancer cells was evaluated and results confirmed that there was a significant change in $10 \mathrm{mg} / \mathrm{ml}$ treatment of latex after $72 \mathrm{hrs}$ on esophageal cancer line and $10 \mathrm{mg} / \mathrm{ml}$ was the optimum concentration in the inhibition of cell line growth [34].

\section{Antidiabetic activity}

Experiment-based studies have shown that F carica and its extract have antidiabetic activity. Antidiabetic effect of methanolic extract of stem bark was carried out and finding confirmed that extract showed significant protection and lowered the blood glucose levels to normal [35]. Another study was performed to evaluate the hypoglycemic effect of an aqueous extract of leaves. Findings of the study showed that extract has a clear hypoglycemic activity in treated versus non-treated diabetic rats [36].

\section{Hepatoprotective effect}

Liver-related diseases are major health problem worldwide and associated with considerable morbidity and mortality. Products based on plants or natural products are popular in the treatment of liver diseases. Experiment was performed on leaves extract and antihepatotoxic activity was tested with $50 \mathrm{mg} / \mathrm{kg}$ of rifampicin. Results of the study confirmed that there was significant reversal of biochemical, histological and functional changes, shows potential hepatoprotective activity [37]. Other study was carried out on ethanolic extract leaves to check the hepatoprotective activity and results showed that extract demonstrated significant hepatoprotection dose- dependent manner [38]. Another study finding confirmed that stem extract treatment prior to methanol intoxication has noteworthy role in protecting animals from hepatic oxidative damage [39]. Hepatoprotective role of latex against lead acetate-induced oxidative stress was evaluated. Outcome of the study revealed that latex noticeably attenuated the prior lead-induced biochemical alterations in serum and liver tissues and histological as well as cellular changes [40].

\section{Hypolipidemic effect}

The study was performed on extract from leaves, could be used to decrease hepatic triglyceride (TG) content and secretion of TG and cholesterol (TC) from the liver. Livers with high abdominal fat pad ratios were extracted, sliced, and cultured with increasing concentrations of extract, insulin and both of them. Whereas insulin considerably increased TG secretion, TG content and TC secretion) higher than the basal levels, when full-time equivalent was added these effects were drastically reduced to the basal levels in a concentration-dependent manner [41].

\section{Antimicrobial effect}

The worldwide emergence of multi-drug resistant bacteria is increasingly and limiting the effectiveness of drugs and significantly causing failure of treatment [42]. However, there is an urgent need to investigate an alternative source with established antimicrobial activity to overcome such problem. Experiment was performed based on different extract of latex to investigate antimicrobial proprieties against bacteria species and strains of fungi. Finding of the study confirmed that methanolic extract had no effect against bacteria except for Proteus mirabilis [43]. Furthermore, ethyl acetate extract showed inhibition effect on the multiplication of five bacteria species and for the opportunist pathogenic yeasts, ethyl acetate and chlorophormic fractions showed strong inhibition [43]. Another study was carried out to investigate the antimicrobial activity of methanol extract against oral bacteria and results revealed that extract showed a strong antibacterial activity against oral bacteria [44]. The extract was screened for antibacterial activity and outcome of study demonstrated that zone of inhibition against P. mirabilis and Bacillus subtilis [24]. Another experiment was made to confirm the ability of latex to interfere with the infection of caprine herpesvirus-1 in vitro. Finding demonstrated that simultaneous addition of latex and CpHV-1 to monolayers kidney cells resulted in a noteworthy reduction of CpHV-1 titers 3 days post-infection and this effect was comparable to that induced by acyclovir [45].

\section{Anti-angiogenic effect}

Anti-angiogenic and anti-proliferative activity of latex extract was investigated using human umbilical vein endothelial cells (HUVECs). Results of the study confirmed that extract could inhibit proliferation and capillary tube [46]. Other study was carried out to evaluate the antiangiogenic effects base on HUVECs and finding observed that the extract inhibited the tube formation of HUVECs [47]. Anti-angiogenesis effect of leaves extract in an air pouch model of inflammation was evaluated. Result revealed that the extract had significant antioxidant activity with total phenolic content of $11.70 \mathrm{mg}$ gallic acid equivalents $/ 100 \mathrm{~g}$ dry sample [48]. Furthermore, it significantly decreased the production of tumor necrosis factor- $\alpha$, prostaglandin E2, and vascular endothelial growth factor, whereas angiogenesis was significantly inhibited through all administered doses [48].

\section{Antispasmodic activity}

An experiment was performed based on aqueous-ethanolic extract to study the antispasmodic effect. Outcome of the finding showed the presence of spasmolytic activity in the ripe dried fruit possibly mediated through the activation of K+ ATP channels [49].

\section{Immunomodulatory effect}

Immunomodulatory effect was evaluated and results of the study confirmed that administration of extract remarkably ameliorated both cellular and humoral antibody response [50]. 
Anthelmintic activity

Anthelmintic activity of the latex was examined and results confirmed that administered in doses of $3 \mathrm{ml} / \mathrm{kg} /$ day was capable in the removal of Syphacia obvelata (41.7\%) [51].

\section{Nematicidal activity}

The methanol extracts from forty plant species were screened to evaluate the nematicidal activity against Bursaphelenchus xylophilus, Panagrellus redivivus, and Caenorhabditis elegans nematodes. Outcome of the study confirmed that leaf extract showed the strongest nematicidal activity causing $74.3 \%, 96.2 \%$, and $98.4 \%$ mortality, respectively [52].

\section{Effect on Alzheimer's disease}

Experiment was made to evaluate the effect of dietary supplementation with $4 \%$ figs on the memory, anxiety, and learning skills and study results showed that $\mathrm{Tg}$ mice fed with control diet without figs showed significant memory deficits, increased anxiety-related behavior, and motor coordination compared to the wild-type control mice fed same diet, and Tg mice fed on 4\% fig diet supplementation [53]. Another study was made to examine the beneficial effects of dietary supplements containing pomegranate, figs, or the dates on suppressing inflammatory cytokines. Finding confirmed that increased levels of inflammatory cytokines and eotaxin activity were decreased by administration of the diet supplements [54].

\section{Effect on sperm parameters}

Experiment was made based to investigate effect of leaf extracts in sperm parameters and testis intoxicated and results of the study showed that extracts improved sperm count, non-progressive motility of spermatozoa, and gonadosomatic index in treated testes [55]. Earlier study concluded that ethanolic extract showed the aphrodisiac activity and this action was dose dependent [56].

\section{Nephroprotective effect}

Medicinal plant or product from the natural source has confirmed role as nephroprotective. Earlier finding has proven nephroprotective effect of Mimosa pudica root, Phyllanthus acidus leaves and Carica papaya [57-59]. Protective effect of hydroalcoholic extract on GMinduced renal proximal tubular damage was evaluated and results revealed extract alone increased catalase concentration, glutathione content and decreased malondialdehyde level [60]. Furthermore, extract supplementation ameliorated GM-induced specific metabolic alterations and oxidative damage [60].

\section{Effect on osteoclastogenesis}

Another study results showed that hexane soluble fraction of the fig is a potent inhibitor of osteoclastogenesis in RANKL-stimulated RAW264.7 cells and in bone marrow-derived macrophages [61].

\section{Effect on ischemia/reperfusion injuries}

Experiment was made to evaluate antioxidant activity and leaves extract effect on ischemia/reperfusion injuries. Outcome of the study revealed that extract showed antioxidant activity and extract decreased number of ventricular ectopic beats, incidence and duration of Rev ventricular fibrillation with clear reduction in infarct size as well as infarct volume [62].

\section{CONCLUSION}

Treatment based on allopath is expensive and also shows adverse complications either in short term or long term. Popularity of alternative medicine and natural products is increasing worldwide due to inexpensive and health promoting activities. In this vista, F carica Linn generally known as Fig is a small deciduous tree and it holds wide-ranging diseases management activities due to a rich source of antioxidant activity. Experimentation based on different types of extract has confirmed their role in diseases cure. Detailed study based on animal model and clinical trials should be conducted to know the safe dose and mode of action in health management.

\section{REFERENCES}

1. Rahmani AH, Aly SM, Ali H, Babiker AY, Srikar S, Khan AA. Therapeutic effects of date fruits (Phoenix dactylifera) in the prevention of diseases via modulation of anti-inflammatory, anti-oxidant and antitumour activity. Int J Clin Exp Med 2014;7(3):483-91.

2. Rahmani AH, Al Shabrmi FM, Allemailem KS, Aly SM, Khan MA. Implications of green tea and its constituents in the prevention of cancer via the modulation of cell signalling pathway. Biomed Res Int 2015;2015:925640.

3. Anonymous. The Wealth of India. Vol. IV. New Delhi: National Institute of Science and Communication; 2002. p. 26-31.

4. Frodin DG. History and concepts of big plant genera. Taxon 2004;53:753-76

5. Tous J, Ferguson L. Mediterranean fruits. In: Janick J, editor. Progress in New Crops, Arlington, VA, USA: SHS Press; 1996. p. 416-30.

6. Farooqi I. Ahadith Mein Mazkoor Nabatat, Adwiya Aur Ghizain. Urdu Bazar Lahore: Ilm-o-Irfan Pulishers; 1998. p. 151-2, 68.

7. Mohan GK, Pallavi E, Kumar BR, Ramesh M, Venkatesh S. Hepatoprotective activity of Ficus carica Linn leaf extract against carbon tetrachloride-induced hepatotoxicity in rats. Daru 2007;15:162-6.

8. Kirthikar KR, Basu BD. Indian Medicinal Plants. $2^{\text {nd }}$ ed. Vol. 3. India: International Book Distributors; 1996. p. 2329-31.

9. Nadkarni KM, Nadkarni AK. Indian Materia Medica. Vol. 1. India: Popular Prakashan; 1995. p. 545-7.

10. Mawa S, Husain K, Jantan I. Ficus carica L. (Moraceae): Phytochemistry, Traditional Uses and Biological Activities. Evid Based Complement Alternat Med 2013;2013:8.

11. Ullman SB. The inhibitory and necrosis-inducing effects of the latex of Ficus carica L. on transplanted and spontaneous tumours. Exp Med Surg 1952;10(1):26-49.

12. Ullman SB, Clark GM, Roan KM. The effects of the fraction R3 of the latex of Ficus carica L. on the tissues of mice bearing spontaneous mammary tumors. Exp Med Surg 1952;10(4):287-305.

13. Chawla A, Kaur R, Sharma AK. Ficus carica Linn. A review on its pharmacognostic, phytochemical and pharmacological aspects. Int $\mathrm{J}$ Pharm Phytopharmacol Res 2012;1:215-32.

14. Josef B, Raj S. Pharmacognostic and phytochemical properties of Ficus carica Linn: An overview. Int J Pharm Tech Res 2011;3:8-12.

15. Oliveira AP, Valentão P, Pereira JA, Silva BM, Tavares F, Andrade PB. Ficus carica L.: Metabolic and biological screening. Food Chem Toxicol 2009;47(11):2841-6.

16. Gibernau M, Buser HR, Frey JE, Hossaert-McKey M. Volatile compounds from extracts of figs of Ficus carica. Phytochemistry 1997;46:241-4.

17. Solomon A, Golubowicz S, Yablowicz Z, Grossman S, Bergman M, Gottlieb HE, et al. Antioxidant activities and anthocyanin content of fresh fruits of common fig (Ficus carica L.). J Agric Food Chem 2006;54(20):7717-23.

18. Teixeira DM, Patão RF, Coelho AV, da Costa CT. Comparison between sample disruption methods and solid-liquid extraction (SLE) to extract phenolic compounds from Ficus carica leaves. J Chromatogr A 2006;1103(1):22-8.

19. Vaya J, Mahmood S. Flavonoid content in leaf extracts of the fig (Ficus carica L.), carob (Ceratonia siliqua L.) and pistachio (Pistacia lentiscus L.). Biofactors 2006;28(3-4):169-75.

20. Abu-Mustafa EA, Tawil E, Fayez E. Constituents of local plants-IV; Ficus carica L., F. sycomorus L. and F. salicofolia L. leaves. Phytochem 1964;3:701-3.

21. Ahmed W, Ahmed Z, Malik A. Triterpenes from the leaves of Ficus carica. Fitoterapia 1990;61:373-5.

22. Çalişkan O, Polat AA. Phytochemical and antioxidant properties of selected fig (Ficus carica L.) accessions from the eastern Mediterranean region of Turkey. Sci Hortic 2011;128:473-8.

23. Jeong WS, Lachance PA. Phytosterols and fatty acids in fig (Ficus carica, var. Mission) fruit and tree components. Food Chem Toxicol 2001;66:278-81.

24. Rahmani AH, Albutti AS, Aly SM. Therapeutics role of olive fruits/ oil in the prevention of diseases via modulation of anti-oxidant, antitumour and genetic activity. Int J Clin Exp Med 2014;7(4):799-808.

25. Soni N, Mehta S, Satpathy G, Gupta RK. Estimation of nutritional, phytochemical, antioxidant and antibacterial activity of dried fig (Ficus carica). J Pharmacogn Phytochem 2014;3:158-65.

26. Yang XM, Yu W, Ou ZP, Ma HL, Liu WM, Ji XL. Antioxidant and immunity activity of water extract and crude polysaccharide from Ficus carica L. fruit. Plant Foods Hum Nutr 2009;64(2):167-73.

27. Park S, Han J, Im K, Whang WK, Min H. Antioxidative and anti- 
inflammatory activities of an ethanol extract from fig (Ficus carica) branches. Food Sci Biotechnol 2013;22:1071-5.

28. Patil VV, Patil VR. Evaluation of anti-inflammatory activity of Ficus carica Linn. leaves. Indian J Nat Prod Resour 2011;2:151-5.

29. Patil VV, Bhangale SC, Patil VR. Evaluation of anti-pyretic potential of Ficus carica leaves. Int J Pharm Sci Rev Res 2010;2:48-50.

30. Hashemi SA, Abediankenari S, Ghasemi M, Azadbakht M, Yousefzadeh Y, Dehpour AA. The effect of fig tree latex (Ficus carica) on stomach cancer line. Iran Red Crescent Med J 2011;13(4):272-5.

31. Khodarahmi GA, Ghasemi N, Hassanzadeh F, Safaie M. Cytotoxic effects of different extracts and latex of Ficus carica L. on HeLa cell Line. Iran J Pharm Res 2011;10(2):273-7.

32. Rubnov S, Kashman Y, Rabinowitz R, Schlesinger M, Mechoulam R. Suppressors of cancer cell proliferation from fig (Ficus carica) resin: Isolation and structure elucidation. J Nat Prod 2001;64(7):993-6.

33. Tezcan G, Tunca B, Bekar A, Yalcin M, Sahin S, Budak F, et al. Ficus carica latex prevents invasion through induction of let-7d expression in GBM cell lines. Cell Mol Neurobiol 2015;35(2):175-87.

34. Hashemi A, Abediankenari S. Suppressive effect of fig (Ficus carica) latex on esophageal cancer cell proliferation. Acta Facultatis Med Naissensis 2013;30:93.

35. Ahmad MZ, Ali M, Mir SR. Anti-diabetic activity of Ficus carica L. stem barks and isolation of two new flavonol esters from the plant by using spectroscopical techniques Asian J Biomed Pharm Sci 2013;3:22-8

36. Perez C, Domínguez E, Ramiro JM, Romero A, Campillo JE, Torres MD. A study on the glycaemic balance in streptozotocin-diabetic rats treated with an aqueous extract of Ficus carica (fig tree) leaves. Phytother Res 1998;10:82-3.

37. Gond NY, Khadabadi SS. Hepatoprotective Activity of Ficus carica leaf extract on rifampicin-induced hepatic damage in rats. Indian $\mathrm{J}$ Pharm Sci 2008;70(3):364-6

38. Mujeeb M, Alam Khan S, Aeri V, Ali B. Hepatoprotective activity of the ethanolic extract of Ficus carica Linn. leaves in carbon tetrachlorideinduced hepatotoxicity in rats. Iran J Pharm Res 2011;10(2):301-6.

39. Saoudi M, El Feki A. Protective role of Ficus carica stem extract against hepatic oxidative damage induced by methanol in male Wistar rats. Evid Based Complement Alternat Med 2012;2012:8.

40. Aziz FM. Protective effects of latex of Ficus carica L. against lead acetate-induced hepatotoxicity in rats. Jordan J Biol Sci 2012;5:175-82.

41. Asadi F, Pourkabir M, Maclaren R, Shahriari A. Alterations to lipid parameters in response to fig tree (Ficus carica) leaf extract in chicken liver slices. Turk J Vet Anim Sci 2006;3:315-8.

42. Hancock RE. Mechanisms of action of newer antibiotics for Grampositive pathogens. Lancet Infect Dis 2005;5(4):209-18.

43. Aref HL, Salah KB, Chaumont JP, Fekih A, Aouni M, Said K. In vitro antimicrobial activity of four Ficus carica latex fractions against resistant human pathogens (antimicrobial activity of Ficus carica latex). Pak J Pharm Sci 2010;23(1):53-8

44. Jeong MR, Kim HY, Cha JD. Antimicrobial activity of methanol extract from Ficus carica leaves against oral bacteria. J Bacteriol Virol 2009;39:97-102.

45. Camero M, Marinaro M, Lovero A, Elia G, Losurdo M, Buonavoglia C, et al. In vitro antiviral activity of Ficus carica latex against caprine herpesvirus-1. Nat Prod Res 2014;28(22):2031-5.

46. Mostafaie A, Mansouri K, Norooznezhad A, Mohammadi-Motlagh H. Anti-angiogenic activity of Ficus carica latex extract on human umbilical vein endothelial cells. Cell J Yakhteh 2011;12:525-8.

47. Ghambarali Z, Bidmeshkipouri A, Akrami H, Azdbakht M, RabziaIndian A. Ethanolic extract of Ficus carica leave suppresses angiogenesis by regulating VEGF-A and integrin $\beta 3$ mRNA expression in human umbilical vein endothelial cells. J Physiol Pharmacol 2014;58:407-15.

48. Eteraf-Oskouei T, Allahyari S, Akbarzadeh-Atashkhosrow A, Delazar A, Pashaii M, Gan SH, et al. Methanolic extract of Ficus carica Linn. leaves exerts antiangiogenesis effects based on the rat air pouch model of inflammation. Evid Based Complement Alternat Med 2015;2015:760405.

49. Gilani AH, Mehmood MH, Janbaz KH, Khan AU, Saeed SA. Ethnopharmacological studies on antispasmodic and antiplatelet activities of Ficus carica. J Ethnopharmacol 2008;119(1):1-5.

50. Patil VS, Bhangale SC, Patil VR. Studies on immunomodulatory activity of Ficus carica. Int J Pharm Pharm Sci 2010;2:97-9.

51. De Amorin A, Borba HR, Carauta JP, Lopes D, Kaplan MA. Anthelmintic activity of the latex of Ficus species. J Ethnopharmacol 1999;64(3):255-8.

52. Liu F, Yang Z, Zheng XM, Luo S, Zhang K, Li G. Nematicidal coumarin from $F$. carica L. J Asia Pac Entomol 2011;14:79-81.

53. Subash S, Essa MM, Braidy N, Al-Jabri A, Vaishnav R, Al-Adawi S, et al. Consumption of fig fruits grown in Oman can improve memory, anxiety, and learning skills in a transgenic mice model of Alzheimer's disease. Nutr Neurosci 2016;19(10):475-483.

54. Essa MM, Subash S, Akbar M, Al-Adawi S, Guillemin GJ. Long-term dietary supplementation of pomegranates, figs and dates alleviate neuroinflammation in a transgenic mouse model of Alzheimer's disease. PLoS One 2015;10(3):e0120964.

55. Naghdi M, Maghbool M, Seifalah-Zade M, Mahaldashtian M, Makoolati Z, Kouhpayeh SA, et al. Effects of common fig (Ficus carica) leaf extracts on sperm parameters and testis of mice intoxicated with formaldehyde. Evid Based Complement Altern Med 2016;2016:9.

56. Palaniyappan V, Bommireddy EP, Gudipudi H, Chitturi RD, Yandamala N. In vivo fertility enhancing activity (Aphrodisiac) of Ficus carica fruit on male wistar rats. Int J Pharm Pharm Sci 2013;5:516-8.

57. Vidya S, Ramesh A, Rajashekar G, Meghana D, Nazeer SK. The nephroprotective activity of methanolic extracts of leaves against gentamicin-induced nephrotoxicity in experimental rodents. Int $\mathrm{J}$ Pharm Pharm Sci 2013;5(4):209-13.

58. Geetha K, Ramarao N, Sindhu B, Rao BU. Nephroprotective, nephrocurative activity of Mimosa pudica root against gentamicin induced nephrotoxicity. Int J Pharm Pharm Sci 2015;7(4):173-7.

59. Rahmani AH, Aldebasi YH. Potential role of Carica papaya and their active constituents in the prevention and treatment of diseases. Int $\mathrm{J}$ Pharm Pharm Sci 2016;8(1):11-5.

60. Kore KJ, Shete RV, Borade AS. Protective role of hydroalcoholic extract of Ficus carica in gentamicin induced nephrotoxicity in rats. Int J Pharm Life Sci 2011;2:978-82.

61. Park YR, Eun JS, Choi HJ, Nepal M, Kim DK, Seo SY, et al. Hexanesoluble fraction of the common fig, Ficus carica, inhibits osteoclast differentiation in murine bone marrow-derived macrophages and raw 264.7. Korean J Physiol Pharmacol 2009;13:417-24.

62. Allahyari S, Delazar A, Najafi M. Evaluation of general toxicity, antioxidant activity and effects of Ficus carica leaves extract on ischemia/ reperfusion injuries in isolated heart of rat. Adv Pharm Bull 2014;4 Suppl 2:577-82. 